\title{
Semi-Strong Form Efficiency in the Baltic Stock Markets under Changing Economic Situation
}

\author{
Vilija Alekneviciene ${ }^{1}$, Lauryna Kviedaraitiene ${ }^{2}$, Egle Alekneviciute ${ }^{3}$ \\ ${ }^{1,2}$ Aleksandras Stulginskis University \\ Universiteto st. 10, LT-53361 Akademija \\ E-mail.vilija.alekneviciene@asu.lt,lauryna.kviedaraitiene@gmail.com
}

${ }^{3}$ Vytautas Magnus University

S. Daukanto g. 28, LT-44246 Kaunas

E-mail.egle.alekneviciute@gmail.com

cross $^{\text {ref }} \underline{\text { http://dx.doi.org/10.5755/j01.ee.29.5.19083 }}$

\begin{abstract}
This study is designed to test semi-strong form efficiency in the Baltic stock markets and to identify investors' behaviour under changing economic situation. It involves description of semi-strong form stock market efficiency and discusses the results of other studies in the field. Analysis and summary of previous research results showed that there are a lot of studies testing semi-strong form efficiency in various stock markets, but only a few analysed Baltic stock markets, especially under changing economic situation. This research employed event study methodology - Patell's, BMP and cumulative abnormal return tests. The chosen research period of 2000-2016 was divided into two sub-periods based on changes of OMX Baltic Benchmark index: January 2000 - March 2009 and April 2009 - December 2016. The research results showed that Lithuanian, Latvian and Estonian stock markets were not efficient in semi-strong form in neither of the sub-periods. The proposition, that thin stock markets are not efficient was confirmed, allowing investors in the Baltic stock markets to earn abnormal returns. In the second sub-period the average abnormal returns increased in all analysed markets, potentially due to increased distrust and precaution of investors. Nevertheless, significance of the difference between the levels of inefficiency in both sub-periods was partly approved in the Baltic stock markets.
\end{abstract}

Keywords: Efficient Market Hypothesis; Semi-Strong Form Efficiency; Stock Markets; Abnormal Returns; Event Studies; Economic Situation.

\section{Introduction}

A well-developed stock market is expected to function efficiently, to have as many participants and money in circulation as possible. Moreover, an efficient stock market allows accurately estimating the price of securities in circulation. An adequate assessment of market efficiency enables determining market conditions, thus giving a better chance to assess the efficiency benefits. Fama (1970), the developer of an Efficient Market Hypothesis (EMH), distinguished three forms of market efficiency: weak, semistrong, and strong. Seeking to test the EMH, researchers have been investigating financial markets' efficiency in different countries, but the results were rather ambiguous, creating space for further discussions and empirical research.

Since the 1970s, most of the studies had been carried out in the largest, most developed stock markets: USA (Chance, 1985) Australia (Goss, 1983), Greece (Alexakis, Patra and Poshakwale, 2010; Apergis and Eleptheriou, 2001; Siourounis, 2002), Hong Kong, United Kingdom, Japan (Coleman, 2012) and others. Even though this topic has not been widely investigated in the Baltic stock markets, Gausiene and Jureviciene (2010), Klimasauskiene and Moscinskiene (1998), Konceviciene (2006), Leipus and Norvaisa (2003) carried out studies in the field. Nevertheless, the studies were not oriented towards semistrong form market efficiency, making it relevant to assess whether the Baltic stock markets were efficient in semi- strong form. Kiete and Uloza (2005) examined whether Lithuanian and Latvian stock markets reacted inefficiently to the earning announcements while Jazepcikaite (2008) analysed how changes in ownership structure affected the Baltic stock markets' efficiency.

Market efficiency has been agreed to be a relative concept. According to Gilson and Kraakman (2014), ,in each market the inquiry must be whether prices in one or more classes of securities responded rapidly (with relative efficiency) to the public release of new, value-relevant information". The strength of market efficiency varies between the markets and over time and is influenced by economic situation. Results of Hoffmann, Post and Pennings (2013) showed that individual investor perceptions changed and drove trading and risk-taking behaviour during the 2008-2009 financial crisis. According to the authors, investor perceptions exhibited significant fluctuations over the course of the crisis, with risk tolerance and risk perceptions being less volatile than return expectations. In the worst months of the crisis, investors' return expectations and risk tolerance decreased, while their risk perceptions increased. Towards the end of the crisis, return expectations, risk tolerance, and risk perceptions recovered. This again showed that investors' actions, stock prices, and, consequently, market efficiency depended on economic situation and created a niche for research in the field. 
How could investors benefit from semi-strong form inefficiency? They could predict future security prices by using publicly available information as well as earn abnormal returns. However, no trader could earn profit without another trader losing. As Harris (1993) pointed out, markets would not exist without utilitarian trades. Their trading losses fund the winning traders who make prices efficient and provide liquidity. Despite of this, risk aversion and pessimistic sentiments of trading losers increase their distrust, slowing down the movement towards markets' liquidity and efficiency.

Findings of Chordia, Roll and Subrahmanyam (2008) indicated that liquidity stimulated arbitrage activity, which, in turn, enhanced market efficiency. They also found an increased incorporation of private information into prices during more liquid regimes. Hodrea (2015) investigated the relationship between market efficiency and liquidity in an emerging market. According to the author, market liquidity has a positive impact on informational efficiency, and increase in liquidity leads to greater efficiency.

Despite the fact that emerging markets are usually less liquid and efficient, market operators try to enhance both parameters. INET Nordic - NASDAQ trading platform was introduced for Nordic and Baltic equities trading in 2010 in order to increase the trading volumes and market liquidity. NASDAQ OMX Baltic Market Making Program was launched on July 1, 2013. In order to encourage members to join this voluntary program and contribute to higher liquidity, NASDAQ OMX has offered a $40 \%$ discount on the standard trading fees. Liquidity providers connect brokers and traders, increasing the liquidity of the joint market. A higher liquidity is desirable for everyone, as it drives down the market spreads and the cost of trading.

There are only a few studies made in the Baltic stock markets. They mostly showed the semi-strong inefficiency or were controversial. Furthermore, market efficiency is a relative concept. Some recent studies proved that market efficiency varies between the markets and over time as well, as it is influenced by economic situation. These reasons encouraged testing semi-strong form efficiency in the Baltic stock markets over a relatively long period (2000-2016) and allowed to identify investors' behaviour under changing economic situation.

\section{Literature Review}

An efficient market was commonly described as nonexistent, where all the information was publicly available and prices reflected historical information, not allowing to earn excess returns. Even if the concept of an efficient market theory was broad, in reality it was limited and frequently narrowed down to the EMH (Fama, 1970; Goss, 1983; Klimasauskiene and Moscinskiene, 1998; Leipus and Norvaisa, 2003; Schaffer, Myers \& Koontz, 2004).

One of the first researchers to describe an effective market hypothesis was Fama (1970) who highlighted the availability and publicity of information, and argued that market was efficient if prices fully incorporated the available information and there was a large number of participants. Similarly, Goss (1983) systemized the conditions for fullyefficient market: competitiveness, rational use of information, free access to public information, no transaction costs, economic agents' risk neutrality, knowledge and acknowledgement of the consequences of existing and future information by all market participants.

Fama (1970) identified three levels of market efficiency: weak, semi-strong and strong. According to the author, market was weak form efficient if stock prices instantly and fully reflected all the past price information; it was semistrong form efficient if stock prices fully reflect all public information, and strong form efficient if stock prices fully reflect all public and inside information.

Some researchers, such as Bowman and Bucharan (1995), argued that markets were not simply either efficient or inefficient - their efficiency could vary from strong form efficient to inefficient. Consequently, any market or security could be characterised by some degree of efficiency. Will (2006) argued that EMH had a twofold function: it could be used as a theoretical predictive model for financial market operations as well as a technique to attract more investors.

Various studies were carried out to determine the efficiency of different financial markets. Ito and Sugiyama (2009) proved that the degree of market inefficiency varied through time, while analysis of Vosvorda, Filacek and Kapicka (1998) allowed them to reject the weak form market efficiency in Prague Stock Exchange. Cajueiro, Gogas and Tabak (2009) evaluated if the financial market liberalization changed the degree of market efficiency in Greece and showed that changes in financial market liberalization had positive implications on stock market efficiency. Apergis and Eleptheriou (2001) found persistence in volatility clustering which they interpreted as inefficiency of the Athens stock exchange, while Siourounis (2002) detected inefficiency in Athens stock exchange markets. Borges (2010) applied the tests of weak form market efficiency to stock markets in France, Germany, the UK, Greece, Portugal and Spain and found that daily returns were abnormally distributed, negatively skewed and leptokurtic. Ziliotto and Serati (2015) analysed the EURO STOXX 50 market index and found that significant price deviations from equilibrium (inefficiencies) could occur by deliberately modelling situations with pre-emptive leaks of public information.

The theory of semi-strong form market efficiency and its research is still under development and investigation by researchers from all over the world in various financial markets. Semi-strong market efficiency was considered to be special because current stock prices revealed not only past prices but the information accessible to all investors as well. If the capital market was semi-strong form efficient, all the market participants would be familiar with the company's information and could not use it to earn excess return (Klimasauskiene and Moscinskiene, 1998; Dietrich et al., 2001). Tests of semi-strong form market efficiency could be divided into two main groups, identified by Derdas (2012), Kancerevycius (2009), Minjina and Resceanu (2008) as direct and indirect methods. According to Kancerevycius (2009), indirect methods were aimed at predicting future price developments by using all publicly available information while direct methods were aimed at determining the possibility to earn abnormal returns by investing in a particular stock after announcing an important event.

According to Fama (1970), in order to confirm or deny semi-strong form market efficiency, it was needed to investigate different public company announcements. When 
directly analysing semi-strong form market efficiency, most researchers chose typical events such as splitting/merging the stocks or announcements of dividend payments. Some authors also analysed stock price developments after atypical, but significant events such as terrorist attacks (Coleman, 2012).

Sturm (2013) investigated stock market reaction to announcements of operational losses in European financial companies and found significant negative stock price reaction to first press announcement of operational losses. In addition, his results showed that stock market reacted negatively to the settlement announcement as losses were confirmed and the loss amount was known. Sharma (2011) extended the previous studies by assessing how share prices adjusted to the information in dividend announcements and tested the semi-strong form market efficiency. The author analysed stock price reaction to dividend announcements in India and found that investment strategies based on dividend announcement events could not result into significant abnormal returns. Olweny (2012) tried to determine the extent to which dividend announcements had information content, its effect on firm value and what this implied on the semi-strong form efficiency of the Nairobi Stock Exchange. Using event study methodology he found that the information content in dividend announcements affected the firm value and the Nairobi Stock Exchange was not efficient in semi-strong form. Hussin, Ahmed and Ying (2010) analysed the dividend announcement effect and corporate earnings on stock prices in order to test semi-strong form efficiency in Malaysian Stock Exchange. The researchers concluded that the announcements of dividends and earnings were significant signalling effects on the future prospects of the firm, with the dividend effect being significantly stronger than the earning effect. Finally, the authors proved semistrong form market efficiency in the Malaysian stock market. The study of Kumar (2015) supported the semi-strong form market efficiency in Indian banking sector, where a share of banks under investigation showed increasing trend in the average cumulative return after the dividend payment announcements. According to Mackey and Bacon (2017), the semi-strong form of EMH left no possibilities to outperform the market - the prices would be quickly riskadjusted to public information, e.g. stock repurchasing, issue announcements. The authors proved that the market could be semi-strong form efficient with respect to stock repurchase announcements and equity issue announcements.

Robinson and Bangwayo-skeete (2016) adjusted the event study methodology for thin trading to explore semistrong form market efficiency and investigated stock price reaction to major national and international events. The national events were natural disasters, parliamentary elections and credit rating reviews, while the international events - international terrorist incidents, major events surrounding the 2007/2008 crisis or the BREXIT. They found that stock prices only reacted to rare events with major consequences, their reaction was mostly delayed and that was not consistent with the semi-strong form market efficiency. Similarly, Liargovas and Repousis (2010) used an event-study methodology to analyse three major terrorist events and to determine the response of Greek banking sector.

Kiete and Uloza (2005) examined whether Lithuanian and Latvian stock markets reacted inefficiently to earning announcements and, if so, whether it was possible to profit from inefficiencies. They used standard event study methodology with daily trading data from 2001-2004. They found that Lithuanian stock market was semi-strong form efficient and strong form inefficient in economic sense; whereas even the semi-strong form efficiency did not hold in Latvia.

Jazepcikaite (2008) analysed how changes in companies' ownership structure affected Baltic stock markets' efficiency and whether stock markets reacted efficiently to event announcements. The author used standard event study methodology with daily trading data from 2000-2008 to examine the efficiency of the Riga, Tallinn and Vilnius Stock Exchanges and found that changes in ownership structure did not lead to substantial increase in market efficiency.

Several market measures have been introduced in Nordic and Baltic stock exchange markets since 2008 in order to increase the trading volumes and market liquidity: INET Nordic - NASDAQ trading platform (2010) and NASDAQ OMX Baltic Market Making Program (2013). Findings of Chordia, Roll and Subrahmanyam (2008) showed that liquidity stimulated arbitrage activity, which, in turn, enhanced market efficiency, and Hodrea (2015) pointed out that market liquidity had a positive impact on informational efficiency. The mentioned changes in OMX Baltic Market and relationship between market liquidity and efficiency encouraged to test semi-strong form efficiency in the Baltic stock markets.

It is also worth noting that the strength of market efficiency varies between the markets and over time as well as is influenced by economic situation. Hoffmann, Post and Pennings (2013) analysed how investor perceptions changed their behaviour in trading and risk-taking during the crisis of 2008-2009 and found a significant fluctuation. During the worst months of the crisis, investors' return expectations and risk tolerance decreased, while their risk perceptions increased and towards the end of the crisis the perceptions recovered. Roszkowski and Davey (2010) investigated the changes of risk tolerance during the crisis of 2008. The authors highlighted that the decline of risk-tolerance during the crisis was relatively small, but the public perception of the risk inherent in investing has changed more dramatically. In order to determine the efficiency of Chinese stock market, Mahmood et al. (2010) applied EMH and divided the data sample into two periods: before global financial crisis and during the crisis. Their results showed that Chinese stock market was weak form efficient: past data of stock market movements could not be used to earn excess returns and the global financial crisis had no significant impact on market efficiency.

In their study Yao, Ma and He (2014) found that herding behaviour was more pronounced when the markets were declining. Papaioannou et al. (2013) argued that although some confidence in the global financial system after financial crisis has returned, quantitative easing (QE) in advanced economies pushed volatility to low levels and accelerated some investors' shift toward high-risk assets or emerging markets. Moreover, hedge fund managers were becoming more bullish about the financial markets and possibilities for high return, contributing to procyclical investor's behaviour.

Analysis of previous research in the field allowed summarizing that there were a lot of studies testing semi- 
strong form efficiency in different stock markets, but very few analysed Baltic stock markets especially under changing economic situation. Moreover, the majority of recent studies were carried out in emerging rather than developed markets. It is worth noting that these studies were to a large extent newer, usually chose events relevant to the existing companies and markets, showing different market reactions to them. Due to the reasons mentioned, event study has been chosen as a method to test the semi-strong form efficiency in Lithuanian, Latvian and Estonian stock markets under changing economic situation.

\section{Research Methodology and Data}

Earlier studies investigated the reaction of stock markets to various announcements by using different event windows. Anjali and Raju (2017), Deepak and Shollapur (2015), Iqbal and Mallikarjunappa (2007), Jazepcikaite (2008), Kiete and Uloza (2005) used 10- or 15-day event window, Derdas (2012), Westfall (2010), Young and Bacon (2012) used 30-day event window, while Dhar and Chhaochharia (2008) chose 40-day window.

Depending on the research question and selected model, the length of event windows varied, but generally $(-5,+5)$ was preferred with the daily data (Basdas and Oran, 2014). According to the authors mentioned, since selection of a narrower event window would help to isolate the impact of other events that could occur within the same window, it would be favourable to have shorter event windows.

Analysis of previous research allowed determining that most studies of semi-strong form market efficiency were based on event studies. Researchers tended to choose various events: announcements of company's financial results (Iqbal \& Mallikarjunappa, 2007; Gupta, 2006; Derdas, 2012), various "positive" and "negative" events (Jazepcikaite, 2008; Kiete \& Uloza, 2005), dividend announcements (Laidroo, 2008), stock redistribution (Dhar \& Chhaochharia, 2008; Laidroo, 2008), splitting the stocks (Westfall, 2010) and other events.

This study includes all publicly disclosed events about dividends paid and financial statements released. The events chosen were divided into two groups: positive and negative. This division is based on the previous research, such as Bomfim (2003). According to the author, positive policy surprise was the announced value for the target rate that exceeded the market's expectations and in such a way boosted stock market volatility in the short run. The news is considered to be good if the present period earnings are larger than the earnings of the previous period (Elliott,
Morse and Richardson; 1984)). According to Anjali and Raju (2017), the rise in dividend is considered as good news and the market will react to dividend change announcement and increase share prices accordingly. Equivalently, announcement of dividend cut suggests unfavourable prospects and will lead to fall in the companies' stock price. Similarly, Kane, Lee and Marcus (1984) interpreted an announcement of positive dividend announcement as a positive event. In this study, the announcements of higher dividends or higher net profit when compared to the previous period were interpreted as positive events, while the reverse announcements were interpreted as negative. As MacKinlay (1997) proved, the power of event studies to detect abnormal performance was much higher when using daily data rather than monthly, quarterly, or annual data. Consequently, our study employed daily closing stock prices.

Researchers used different periods - from 1 month to 30 years - for the analysis of semi-strong form market efficiency and stock market returns. Kiete and Uloza (2005), who investigated Lithuanian and Latvian stock markets, chose 3 years, while Jazepcikaite (2008) used 6-year historic returns for her analysis in the Baltic stock exchange.

In line with the topic of the research the OMX Baltic Benchmark index (OMX BBGI) value changes were chosen for the division of the research period into two subperiods. According to Baur (2012), Federal Reserve Bank of St. Louis (2009) separated the timeline of Global Financial Crisis from the third quarter of 2007 until the end of 2009. They indicated phase 1 as "initial financial turmoil" from 1st August 2007 to 15th September 2008; described phase 2 as "sharp financial market deterioration" (16th September 2008 to 31st December 2008); defined phase 3 as "macroeconomic deterioration" (1st January 2009 to 31st March 2009) and phase 4 - as a phase of "stabilization and tentative signs of recovery" (1st April 2009 until 4th November 2009). Moreover, the authors defined the crisis from August 2007 until March 2009 as covering the first three phases. This decrease can be seen in Figure 1 which presents the OMX Baltic Benchmark index values from January 2000 to December 2016.

It can be seen from the Figure that OMX BBGI reached its lowest value in March 2009. Consequently, it allowed dividing the research period into two sub-periods: until March 2009 and from April 2009. Further on, these periods are referred to as first sub-period (January 2000 - March 2009) and second sub-period (April 2009 - December 2016).

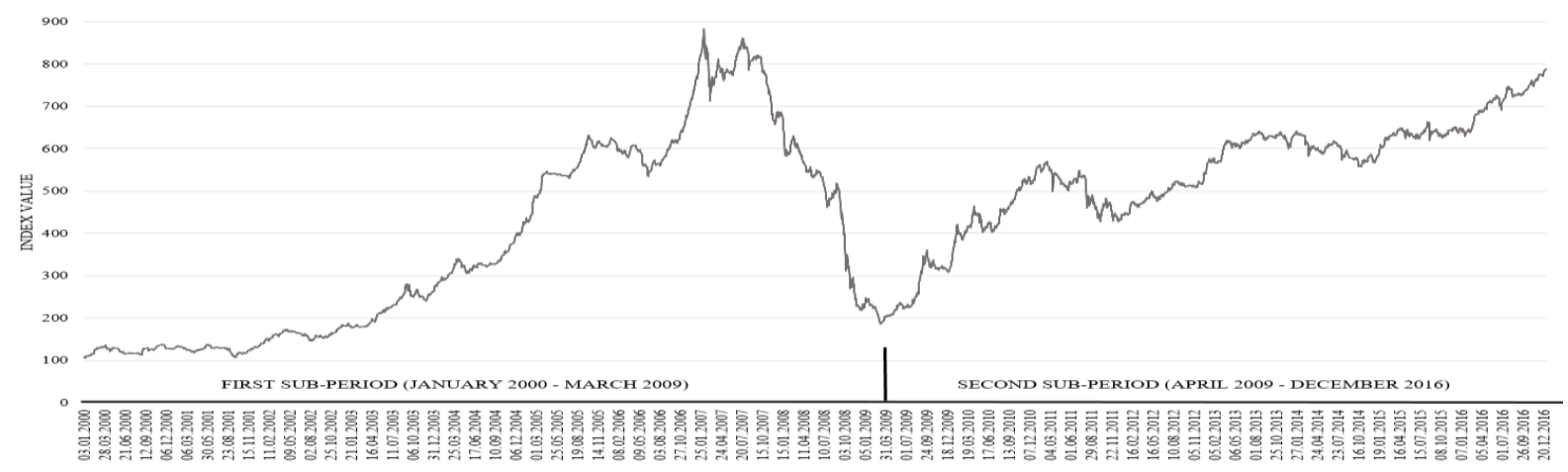

Figure 1. Dynamics of OMX Baltic Benchmark Index in 2000-2016 
In order to assess semi-strong form stock market efficiency and its evolution in different economic subperiods, we selected 39 out of 69 companies from the Nasdaq Baltic securities market (6 Estonian, 15 Lithuanian and 18 Latvian) whose stocks have been traded in at least half of each investigated period.

All public company events have been chosen for this research, so a very short event window would likely lead to several events in one window. Moreover, researchers who analysed the announcements of financial reports and positive or negative events used a 10-day event window. For this reason, 10 days before the event, 10 days after the event and the event day were chosen, making the event window a total of 21 day. Further, stock market prices for each day of this window were identified.

For calculation of one-day stock returns a natural logarithm of the price ratio was used:

$$
R_{i t}=\ln \left(\frac{P_{i t}}{P_{i t-1}}\right)
$$

where: $R_{i t}-$ stock $i$ return at day $t$;

$P_{i t}-$ stock $i$ closing price at day $t$;

$P_{i t-1}-$ stock $i$ closing price at day $t-1$.

Abnormal return on stock $i$ at day $t\left(A R_{i t}\right)$ was calculated:

$$
A R_{i t}=R_{i t}-\bar{R}_{i T}
$$

where: $\mathrm{AR}_{\mathrm{it}}-$ stock $i$ return at day $\mathrm{t}$;

$$
\bar{R}_{i T} \text { - average stock } i \text { return on period T. }
$$

Average return of stock $i$ was calculated as an arithmetic average within the event window:

$$
\bar{R}_{i T}=\frac{\sum_{i=1}^{T} R_{i t}}{T}
$$

where: $T$ - a number of days within the event window.

Variation of an abnormal return was calculated with the following equation:

$$
\sigma_{A R_{i t}}^{2}=\frac{\sum_{t=1}^{T} \varepsilon_{i t}^{2}}{T-2}
$$

In order to test whether the Baltic stock markets were semi-strong form efficient in both sub-periods, three methods were employed: Patell's standardized abnormal returns, cross-sectional model (BMP), and cumulative abnormal returns (CAR).

Calculation of Patell's standardized abnormal returns was chosen to determine whether the abnormal returns were greater than zero during the research period. Patell's statistic $t_{p}$ was calculated with the following equation:

$$
t_{p}=\frac{S A R_{i t} \sqrt{n}}{\sqrt{(T-2) /(T-4)}}=S A R_{i t} \sqrt{\frac{n(T-4)}{(T-2)}}
$$

where:

$S A R_{i t}$ - average of standardized abnormal returns over the sample of $n$ companies on the event day.

Standardized abnormal returns were calculated with the following equation:

$$
S A R_{i t}=\frac{A R_{i t}}{\left(\sigma_{A R_{i t}}^{2}\right)^{1 / 2}}
$$

Jazepcikaite (2008), referring to Patell (1976), argued that an advantage of the method was that it did not require assumptions about the market expectations. However, according to Maynes and Rumsey (1993), the Patell's test rejected a given zero hypothesis too often, which resulted in not always objective calculation of abnormal returns. This fact could significantly distort the results, especially in thin markets (such as the Baltic stock markets). To avoid that, the standardized cross-sectional model was also used in this research.

The model assumed that the stock price changes were constant over time and a significant change could only be caused by an occurrence of a significant event (Boehmer, Masumeci and Poulsen, 1991). To use this method, also known as the BMP method, the events had to be divided into positive and negative. If an event was followed by significantly increased / decreased abnormal returns, the market was not efficient in semi-strong form and needed more time to reflect the fair price of stock. If the market was efficient in semi-strong form, the prices immediately, on the same day, had to reflect all publicly available information.

Calculation of cumulative abnormal returns (CAR) allowed assessing the potential increase in return variations during an event as well as the prediction errors. Boehmer, Masumeci and Poulsen (1991) used it to estimate the crosssectional variance of the standardized abnormal returns. According to Kolari and Pynnonen (2010), if the event day was the same for the firms, the Patell's and BMP $t$-statistics did not account for contemporaneous return correlations. The advantage of the Patell (1976) method, as well as the BMP (1991), was that they weighted individual observations by the inverse of the standard deviation, which implied that more volatile observations got less weight in averaging than the less volatile and hence more reliable observations.

The BMP test took the following form (Boehmer, Masumeci and Poulsen, 1991):

$$
t_{B M P}=\frac{\frac{1}{n} \sum_{i=1}^{n} S A R_{i t}}{\sqrt{\frac{1}{n(n-1)} \sum_{i=1}^{n}\left(S A R_{i t}-\frac{1}{n} \sum_{j=1}^{n} S A R_{j t}\right)^{2}}}
$$

We could aggregate both across companies and over time to form a single test statistic for examining the null hypothesis that the average multi-horizon (cumulative) return across all companies was zero. We would get an equivalent statistic whether we first aggregated over time and then across companies or the other way around. CAR's were calculated with the following equation:

$$
\operatorname{CAR}\left(T_{1}, T_{2}\right)=\frac{1}{n} \sum_{i=1}^{n} C A R_{i}\left(T_{1}, T_{2}\right)
$$

where: $T_{1}$ - a number of days before the event;

$T_{2}-$ a number of days after the event.

In order to obtain the variance of $\operatorname{CAR}\left(T_{1}, T_{2}\right)$ we could take $1 / \mathrm{n}$ multiplied by the average of the variances of the individual $C A R_{i}$ :

$$
\sigma^{2}\left(C A R\left(T_{1}, T_{2}\right)\right)=\frac{1}{n^{2}} \sum_{i=1}^{n} \sigma^{2}\left(C A R_{i}\left(T_{1}, T_{2}\right)\right)
$$

A standard normally distributed test statistic would be:

$$
t_{C A R\left(T_{1}, T_{2}\right)}=\frac{\operatorname{CAR}\left(T_{1}, T_{2}\right)}{\left[\sigma^{2}\left(\operatorname{CAR}\left(T_{1}, T_{2}\right)\right)\right]^{1 / 2}}
$$


The choice of three different methods to test the semistrong form market efficiency provided an opportunity for a complex and more reasoned confirmation or denial of the EMH in Lithuanian, Latvian and Estonian markets.

The parametric t-test results for efficiency are presented at $95 \%$ level of significance. In order to check the robustness of the assessment of the difference between the levels of efficiency or inefficiency in both sub-periods in the Baltic stock markets, t-test (Paired Two-Sample for Means) was applied.

\section{Research Results}

The research results showed that even before the economic crisis there were 18 companies with average negative abnormal returns - significantly more than in the aftermath of the economic crisis when there were 10 such companies. The variations of abnormal returns were also more stable in the first sub-period: values mostly varied from 0 to 0.004 , while in the second sub-period there were even 6 companies whose variation indicator exceeded 0.004 , so the spread of the average abnormal returns was higher. Even if these data did not provide a deeper insight into market efficiency, they were essential for this research. The results of employing three different methods for determining the semi-strong form efficiency in the Baltic stock markets are presented further.

\section{Patell's Standardized Abnormal Returns}

In order to identify the significance of publicly announced events for stock prices in the Baltic stock markets, we firstly calculated Patell's standardized abnormal returns $\mathrm{SAR}_{\text {it }}$ and standardized residual values $t_{\mathrm{p}}$ for Lithuanian, Latvian and Estonian companies (Table 1). The standardized residual values indicated the deviation of included values from the theoretical model. Calculation of the indicators in Table 1 was based on 1132 events (announcements of financial statements or dividend payments).

Table 1 clearly demonstrates that in both sub-periods the event announcements had a significant impact on stock prices - in all the three Baltic markets stock prices responded to the event announcements on the day of announcement and two days before the announcement. The findings showed that in Estonian stock market $t_{p}$ tended to significantly increase three days before the announcement. It could have been influenced by the outbreak of information or speculation in the market. To reduce the effects of speculation or information leakages i.e. to make the market more transparent, "Investor's Calendars" were published, where investors could see the exact dates of the events planned.

In summary, it could be stated that Patell's standardized abnormal returns revealed Lithuanian, Latvian and Estonian stock markets not being semi-strong form efficient $-t_{p}$ were not equal to 0 ( $p>0.05)$. Estonian market has been identified as the most efficient, Latvian - as the least efficient.

Comparison of the markets revealed that after the economic crisis standardized average abnormal returns increased in all the markets investigated: 0.02 percentage points in Lithuanian and Latvian, and 0.38 percentage points in Estonian. This could be explained by decreased investors' risk tolerance and increased risk aversion after the economic crisis potentially due to increased distrust and precaution of investors.

It should be also noted that in Lithuanian and Latvian companies event announcements affected stock prices stronger during the second sub-period, while in Estonian, contrarily, the difference between the levels of inefficiency was not approved. The variance of $t_{p}$ in Lithuanian companies increased from 0.0002 to $0.003(\mathrm{p}<0.05)$, while in Latvian companies - from 0.002 to $0.003(\mathrm{p}<0.05)$.

However, Patell's standardized abnormal returns were not sufficient to expose the semi-strong form market efficiency. According to various researchers, this method was too conservative and often rejected the EMH. Consequently, it should be jointly used with the other methods.

Table 1

Patell's Standardized Abnormal Returns in Lithuanian, Latvian and Estonian Stock Exchange in Two Sub-Periods

\begin{tabular}{|c|c|c|c|c|c|c|c|c|c|c|c|c|}
\hline \multirow{3}{*}{ Days } & \multicolumn{4}{|c|}{ Lithuanian } & \multicolumn{4}{|c|}{ Latvian } & \multicolumn{4}{|c|}{ Estonian } \\
\hline & \multicolumn{2}{|c|}{$\begin{array}{c}\text { January } 2000- \\
\text { March } 2009\end{array}$} & \multicolumn{2}{|c|}{$\begin{array}{c}\text { April 2009- } \\
\text { December } 2016\end{array}$} & \multicolumn{2}{|c|}{$\begin{array}{c}\text { January } 2000- \\
\text { March } 2009\end{array}$} & \multicolumn{2}{|c|}{$\begin{array}{c}\text { April } 2009- \\
\text { December } 2016 \\
\end{array}$} & \multicolumn{2}{|c|}{$\begin{array}{c}\text { January } 2000- \\
\text { March } 2009 \\
\end{array}$} & \multicolumn{2}{|c|}{$\begin{array}{c}\text { April 2009- } \\
\text { December } 2016\end{array}$} \\
\hline & $\mathrm{SAR}_{\text {it }}$ & $t_{p}$ & $\mathrm{SAR}_{\mathrm{it}}$ & $t_{p}$ & $\mathrm{SAR}_{\text {it }}$ & $t_{p}$ & $\mathrm{SAR}_{\mathrm{it}}$ & $t_{p}$ & $\mathrm{SAR}_{\text {it }}$ & $t_{p}$ & $\mathrm{SAR}_{\text {it }}$ & $t_{p}$ \\
\hline-10 & -0.016 & -0.003 & 0.0372 & -0.045 & -0.308 & -0.065 & 0.027 & -0.047 & -0.330 & -0.122 & -1.831 & -0.441 \\
\hline-9 & -0.055 & -0.012 & -0.2502 & -0.106 & 0.227 & 0.048 & 0.043 & -0.044 & 1.171 & 0.195 & -0.215 & -0.099 \\
\hline-8 & 0.014 & 0.003 & 0.2422 & -0.002 & -0.080 & -0.017 & 0.163 & -0.018 & 0.231 & -0.004 & 2.444 & 0.464 \\
\hline-7 & 0.013 & 0.003 & -0.2060 & -0.097 & 0.002 & 0.000 & -0.133 & -0.082 & -0.818 & -0.226 & 0.224 & -0.006 \\
\hline-6 & -0.016 & -0.003 & 0.0744 & -0.038 & 0.084 & 0.018 & -0.648 & -0.190 & 1.376 & 0.238 & -0.931 & -0.250 \\
\hline-5 & 0.049 & 0.010 & -0.0191 & -0.057 & -0.083 & -0.017 & -0.053 & -0.064 & -0.154 & -0.086 & -0.045 & -0.062 \\
\hline-4 & 0.105 & 0.022 & 0.1789 & -0.015 & -0.043 & -0.009 & 0.051 & -0.042 & -1.349 & -0.339 & -1.752 & -0.423 \\
\hline-3 & 0.002 & 0.000 & 0.0211 & -0.049 & -0.112 & -0.023 & 0.062 & -0.040 & -0.776 & -0.217 & 2.823 & 0.544 \\
\hline-2 & 0.062 & 0.013 & -0.3216 & -0.121 & -0.268 & -0.057 & 0.179 & -0.015 & 1.237 & 0.208 & 3.593 & 0.707 \\
\hline-1 & -0.123 & -0.026 & -0.2442 & -0.105 & -0.028 & -0.006 & -0.167 & -0.089 & -0.102 & -0.074 & 0.276 & 0.005 \\
\hline 0 & 0.096 & 0.020 & 0.4834 & 0.049 & 0.135 & 0.029 & 0.357 & 0.022 & 0.673 & 0.089 & 0.679 & 0.091 \\
\hline 1 & 0.176 & 0.037 & 0.9105 & 0.140 & 0.651 & 0.138 & 0.630 & 0.081 & 0.893 & 0.136 & 10.090 & 2.081 \\
\hline 2 & -0.013 & -0.003 & 0.0593 & -0.041 & 0.399 & 0.085 & 0.083 & -0.036 & -0.055 & -0.064 & 8.020 & 1.642 \\
\hline 3 & 0.147 & 0.031 & 0.0111 & -0.051 & -0.139 & -0.030 & 0.526 & 0.058 & 1.145 & 0.189 & -1.209 & -0.309 \\
\hline 4 & 0.055 & 0.011 & 0.0673 & -0.039 & -0.134 & -0.029 & -0.219 & -0.099 & 0.170 & -0.017 & -2.152 & -0.508 \\
\hline 5 & 0.002 & 0.000 & 0.0251 & -0.048 & -0.238 & -0.050 & -0.201 & -0.096 & -0.996 & -0.264 & 2.374 & 0.449 \\
\hline 6 & 0.087 & 0.018 & 0.0342 & -0.046 & -0.028 & -0.006 & 0.109 & -0.031 & 0.810 & 0.118 & -0.177 & -0.091 \\
\hline 7 & -0.020 & -0.004 & -0.0060 & -0.054 & -0.284 & -0.060 & -0.076 & -0.069 & 1.411 & 0.246 & -1.112 & -0.289 \\
\hline 8 & -0.078 & -0.016 & -0.0040 & -0.054 & 0.127 & 0.027 & -0.210 & -0.098 & 1.072 & 0.173 & 1.941 & 0.357 \\
\hline 9 & 0.049 & 0.010 & -0.0513 & -0.064 & 0.050 & 0.010 & -0.147 & -0.084 & 1.667 & 0.299 & -4.111 & -0.922 \\
\hline 10 & 0.128 & 0.027 & 0.0171 & -0.050 & 0.050 & 0.010 & 0.105 & -0.031 & 1.333 & 0.228 & -2.220 & -0.522 \\
\hline
\end{tabular}




\section{Cross-Sectional Model (BMP)}

The second method used to measure market responses to positive and negative events was standardized crosssectional or BMP method. A total of 652 positive and 480 negative events were selected to determine the semi-strong form market efficiency in Lithuanian, Latvian and Estonian stock markets for both sub-periods.

The response of Lithuanian stock market to positive and negative events, presented in Figure 2, showed a decrease of abnormal returns after the negative events were announced. In the first sub-period the maximum negative average abnormal returns were recorded on the second day after the event announcement, but the changes have been small - around 0.01 percentage points. Significance of $t_{B M P}$ values was also dependent on the average abnormal returns and the major deviations were monitored 2-3 days after the event announcement in the second sub-period. In this subperiod the average abnormal returns in Lithuanian stock market significantly increased on the positive event announcement day and one day after it, while in the first sub-period - on the event announcement day and 2-3 days after it. The results showed the highest values on the second and the third days after the event announcement, indicating that the market did not respond immediately and was not efficient in semi-strong form in both sub-periods. Moreover, the difference between the levels of inefficiency was approved for both negative and positive events, and it was higher in the second sub-period. Variance of $t_{\mathrm{BMP}}$ increased from 0.0002 to $0.001(\mathrm{p}<0.05)$ for positive events, and from 0.0002 to $0.0006(\mathrm{p}<0.05)$ - for negative events.

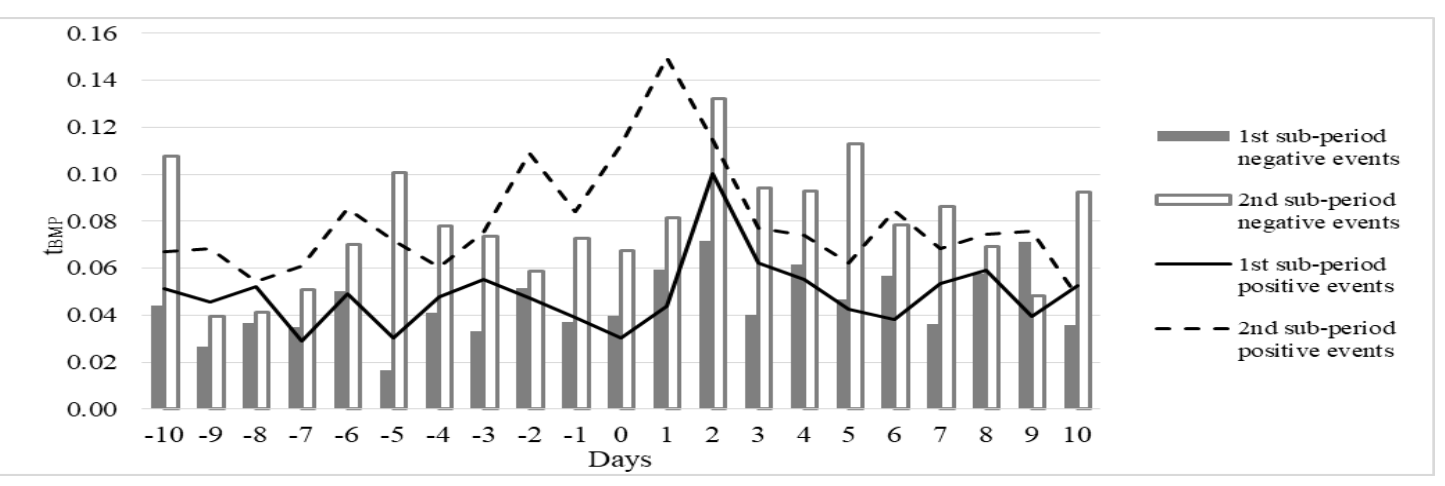

Figure 2. Average Abnormal Returns in Lithuanian Stock Market after Announcing the Positive and Negative Events in Two Sub-periods

Figure 3 presents the reaction of Latvian stock market to positive and negative event announcements, which was similar to the one in Lithuania. In the first sub-period we observed a smaller increase in abnormal returns on the positive event announcement day and 2-3 days after it, while in the second sub-period significantly stronger increase in average abnormal returns was observed immediately after the positive event announcement. In this case, the values of $t_{\text {BMP }}$ also reflected the situation of average abnormal returns: for both sub-periods analysed, the highest values were recorded on the positive event announcement day and three days after it. It revealed that the market did not immediately react to the announced information and gave the opportunity to earn abnormal returns. However, the reaction of Latvian stock market to both positive and negative events was not similar to Lithuanian's, because the significance of the difference between the levels of inefficiency was not approved.

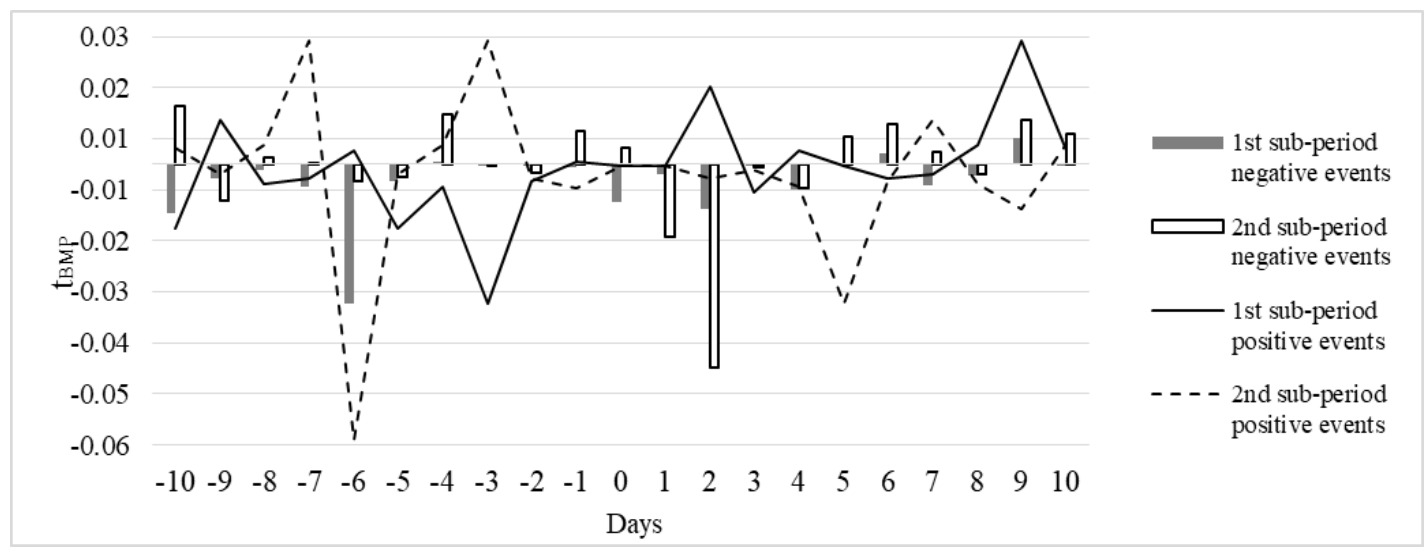

Figure 3. Average Abnormal Returns in Latvian Stock Market after Announcing the Positive and Negative Events in Two Sub-Periods

Reaction of Estonian stock market to positive event announcements was similar to that of Lithuania and Latvia (Figure 4). In the second sub-period the highest abnormal returns were earned 1-2 days after the positive event announcement, while in the first sub-period Estonian stock market was also inefficient in semi-strong form - on the event day and the day after it the average abnormal returns were earned. The values of $t_{\text {BMP }}$ in Estonian stock market 
were the highest on the event announcement day and two days after it, showing that the market was not semi-strong form efficient. The average abnormal returns before and after the negative announcements increased before the announcement and fell below zero on the announcement day in both analysed sub-periods, again proving semi- strong form inefficiency in Estonian stock market. The reaction of Estonian stock market to both positive and negative events was similar in both sub-periods, so the difference between the levels of inefficiency was not approved.

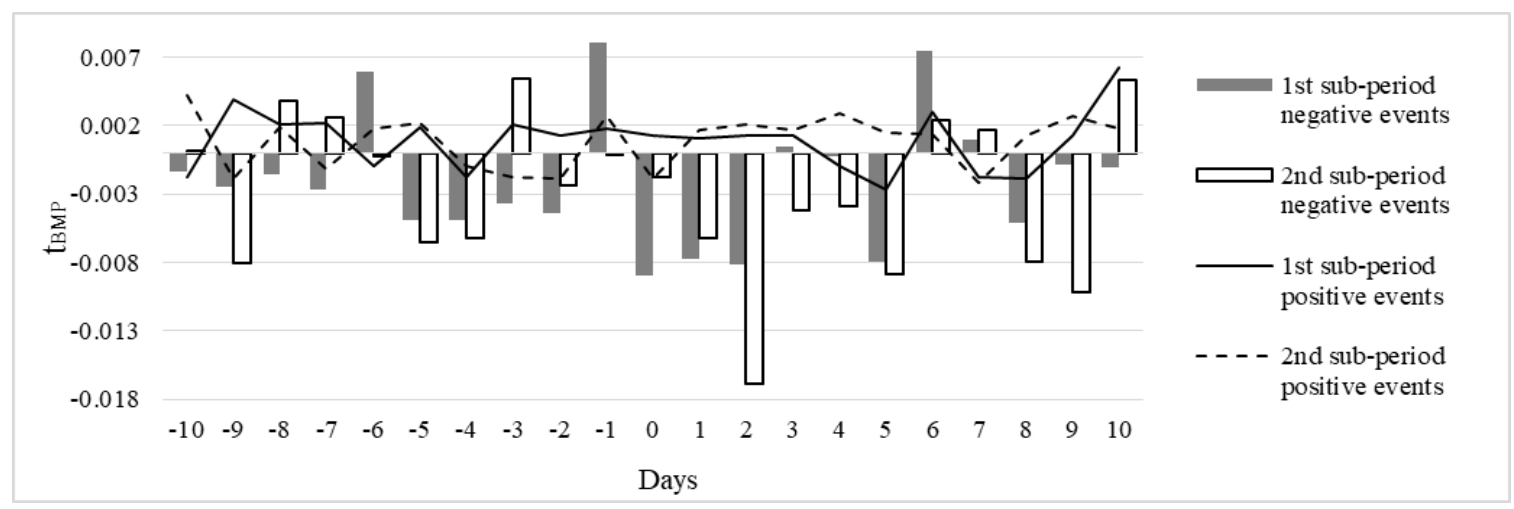

Figure 4. Average Abnormal Returns in Estonian Stock Market after Announcing the Positive and Negative Events in Two Sub-Periods

After assessing the changes in the average abnormal returns and the changes in $t_{B M P}$ values in Lithuanian, Latvian and Estonian stock markets, it could be concluded that none of the analysed markets was efficient in semistrong form: the average abnormal returns were significantly higher on the announcement days and 2 to 3 days after it. It indicates that markets did not immediately react to new information, and the prices did not reflect all the publicly announced information.

\section{Cumulative Abnormal Returns (CAR)}

Cumulative abnormal returns (CAR) show how strongly abnormal returns were cumulated 10 days after the event announcement day. As already mentioned, investors could earn abnormal returns in the following day and few days after the positive event announcement. All three Baltic stock markets reacted to announced events. The upward changes were observed on the announcement day or the following day, while downward changes - on the announcement day or the following 2 days (Figures 5, 6 and 7). Further, all the CAR curves were approaching zero -markets were adapting to the information received, significantly reducing the opportunity to earn abnormal returns. Consequently, it could be concluded that the market reaction was quick, but the adaptation to it was slow.

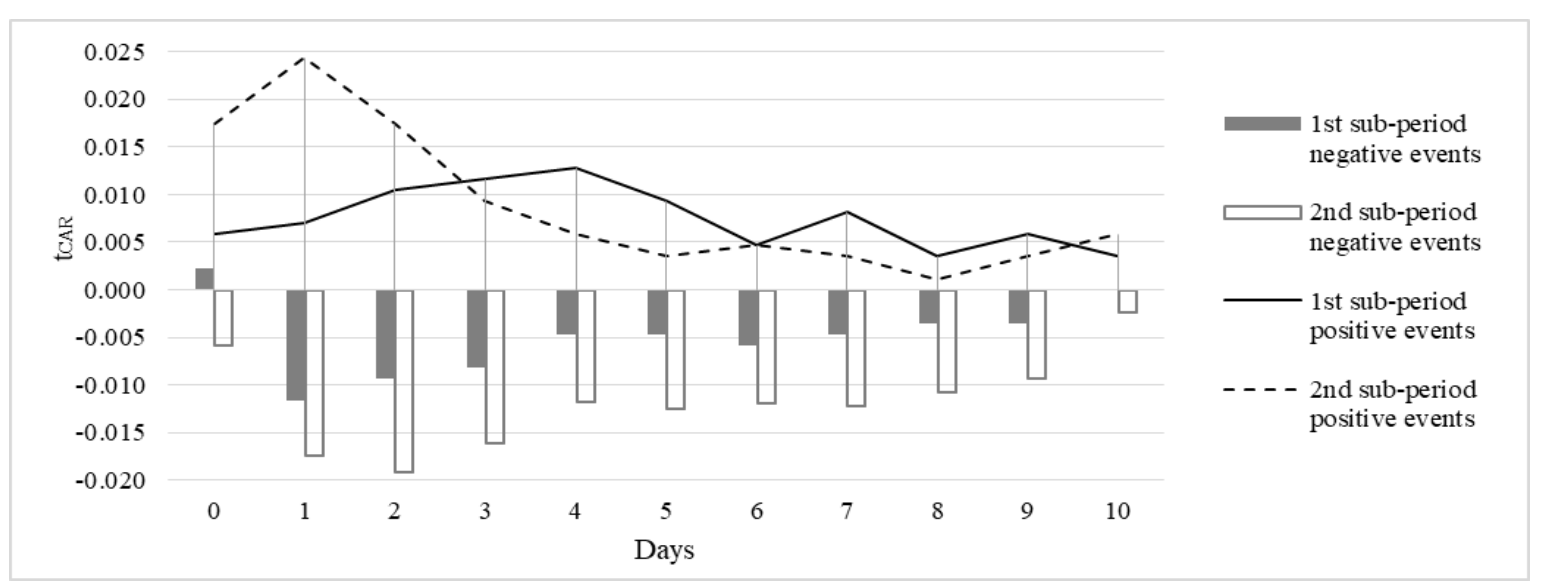

Figure 5. Changes in Cumulated Abnormal Returns in Lithuanian Stock Market after Announcing Positive and Negative Events in Two Sub-Periods

The results of CAR were similar to the ones of BMP Latvian stock market demonstrated higher abnormal returns in both sub-periods when compared to Lithuanian and Estonian markets. Markets' reaction differed with respect to positive and negative news. The research results showed that in Lithuanian market CAR sensitivity to positive events was similar in both sub-periods, while sensitivity to negative events was higher in the second sub-period, so the increase of pessimism and underreaction of investors after financial crisis was confirmed. The changes of Latvian and Estonian markets' reaction were different from Lithuanian: CAR sensitivity to positive events increased after financial crises, while sensitivity to negative events did not change. These findings confirmed the increased overreaction of investors. 


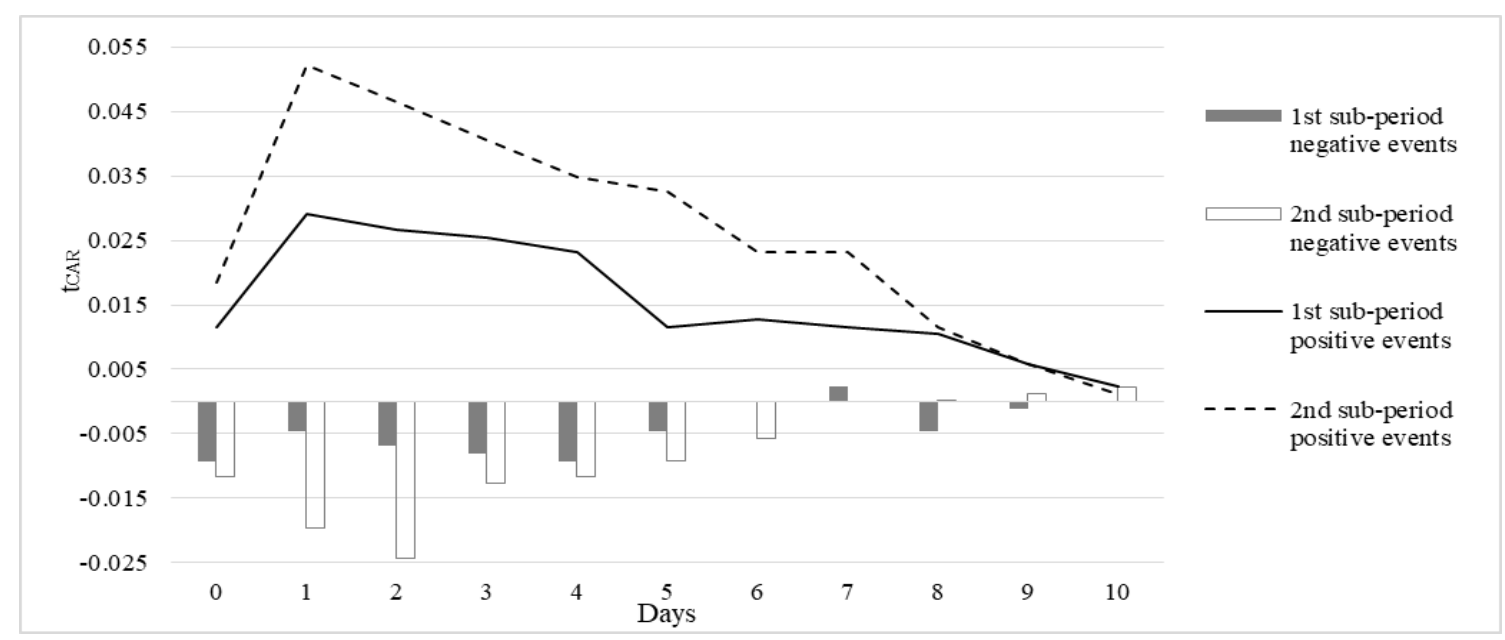

Figure 6. Changes in Cumulated Abnormal Returns in Latvian Stock Market After Announcing Positive and Negative Events in Two Sub-Periods

Results of this study showed that while the potential for earning abnormal returns has not significantly increased, there were still a lot of opportunities to use market inefficiency and earn abnormal returns by instantly reacting to the announcements. In all three stock markets investor, promptly identifying positive events and acquiring the stocks at the same day, could earn abnormal profits by selling them few days later. In case of negative events, prompt stock sale and repurchase in a few days could also allow investor to earn abnormal profits.

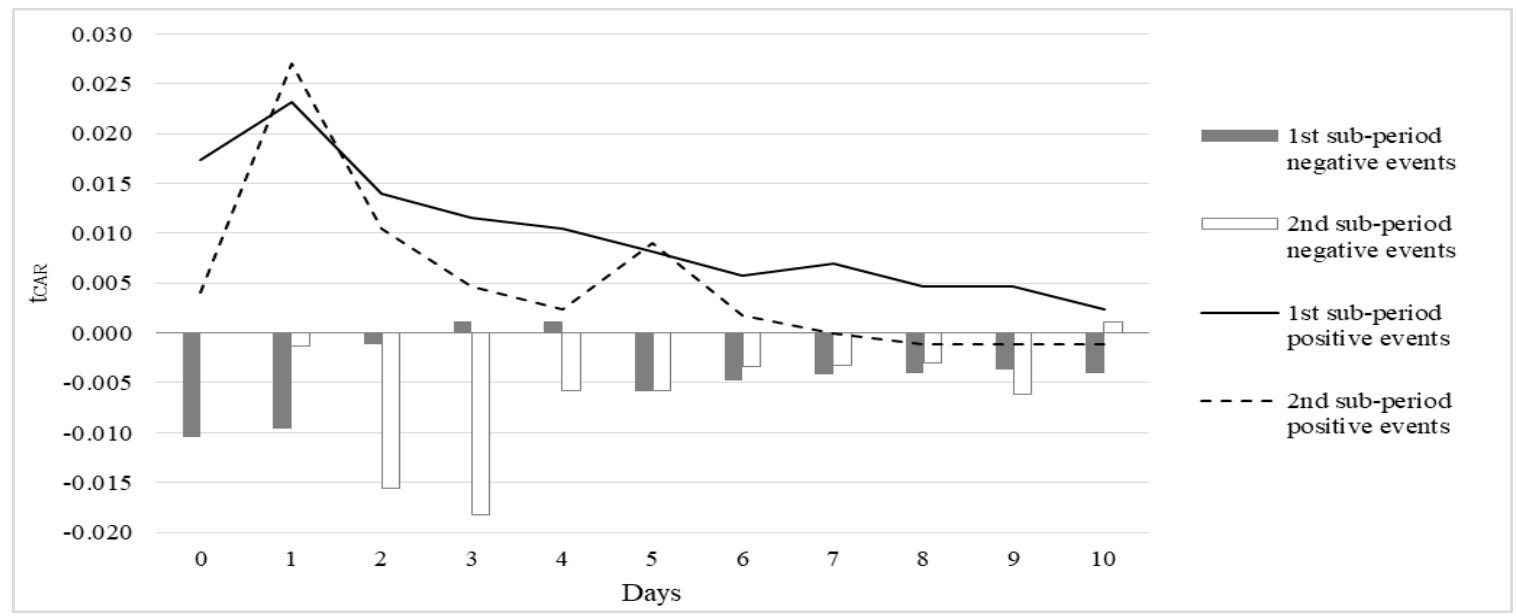

Figure 7. Changes in Cumulated Abnormal Returns in Estonian Stock Market After Announcing Positive and Negative Events in Two Sub-Periods

\section{Conclusions}

An adequate assessment of market efficiency enabled determining the market conditions, thus giving a better chance to capture the efficiency benefits. It is not surprising that smaller and thinner stock markets are not efficient due to the lower liquidity. However, market efficiency has been agreed to be a relative concept, influenced by market liquidity, especially in emerging markets. The strength of market efficiency varies between the markets and over time as well as is influenced by economic situation. In order to test that, we separated the period of 2000-2016 into two subperiods, based on the dynamics of OMX Baltic Benchmark index: until March 2009 and from April 2009. Further on, these periods are referred to as first sub-period (January 2000 - March 2009) and second sub-period (April 2009 December 2016).
Combination of three different tests (Patell's, BMP and cumulative abnormal return) allowed determining that all three Baltic stock markets were not semi-strong form efficient in both research sub-periods. Estonian market was the most efficient, Latvian - as the least efficient. The implication of this study is that investors can benefit from the announcements of financial statements or dividend payments. The findings revealed that companies are not successful in disseminating the information to the investors or immediate reaction due to thin trading is not possible. They will help the stock market regulators to initiate measures to ensure market efficiency.

Patell's standardized abnormal return test, considered to be very conservative, showed that event announcements in Lithuanian and Latvian companies affected stock prices significantly stronger during the second sub-period, while in 
Estonian companies the difference between the levels of inefficiency was not approved. The findings confirmed that the behaviour of investors in Estonian market did not change after financial crises.

Application of BMP test provided similar results: none of the analysed markets were semi-strong form efficient. Average abnormal returns were significantly higher on the announcement days and 2 to 3 days after it. Difference between the levels of inefficiency was approved for both negative and positive events, and it was higher in the second sub-period in Lithuanian market, while in Latvian and Estonian markets this difference was not observed. The results allowed making a conclusion that financial behaviour was relatively different considering the changes of economic situation.

The findings revealed that in Lithuanian market CAR sensitivity to positive events was similar in both sub-periods, while sensitivity to negative events was higher in the second sub-period. We confirmed the increase of pessimism and underreaction of investors after the financial crisis. The changes of Latvian and Estonian markets' reaction were different from Lithuanian: CAR sensitivity to positive events increased after financial crises, while sensitivity to negative events did not change. We confirmed the increased overreaction of investors.
Generally, it was determined that financial crisis caused variations in semi-strong form market inefficiency between Baltic Stock Markets. However, these variations differed in each investigated market-Lithuanian, Latvian and Estonian.

The primary limitation in our analysis is that all our conclusions should be considered with caution. For example, when announcements of financial statements or dividend payments were posted earlier in other sources than in stock exchanges, the reaction of the markets could be distorted. In addition, stock prices could be affected by other events or factors in the chosen event window.

This research provides the insights on possible actions of domestic investors in stock markets based on economic situation. Further research direction could be assessing why a higher level of inefficiency has been recorded after the economic crisis in Lithuanian and Latvian stock markets, while in Estonian stock market not.

Consequently, it would be relevant to assess the behaviour of Lithuanian, Latvian and Estonian investors, especially their rationality and underreaction or overreaction as well. It would be also important to analyse the prices and investors' reactions to other types of events, such as changes in company executives or macroeconomic events related to the sector company operates in.

\section{References}

Alexakis, C., Patra, T., \& Poshakwale, S. (2010). Predictability of stock returns using financial statement information: evidence on semi-strong efficiency of emerging Greek stock market. Applied Financial Economics, 20(16), 13211326. https://doi.org/10.1080/09603107.2010.482517

Anjali, R., \& Raju, G. A. (2017). Dividend Announcement and Market Efficiency-An Empirical Study on Service Sector Companies Listed in BSE. SDMIMD Journal of Management, 8(1). https://doi.org/10.18311/sdmimd/2017/15714

Apergis, N., \& Eleptheriou, S. (2001). Stock returns and volatility: Evidence from the Athens stock market index. Journal of Economics and Finance, 25, 50-61. https://doi.org/10.1007/BF02759686

Basdas, U., \& Oran, A. (2014). Event studies in Turkey. Borsa Istanbul Review. https://doi.org/10.1016/j.bir.2014.03.003

Baur, D. G. (2012). Financial contagion and the real economy. Journal of Banking and Finance, 36(10), $2680-2692$. https://doi.org/10.1016/j.jbankfin.2011.05.019

Boehmer, E., Masumeci, J., \& Poulsen, A. B. (1991). Event-study methodology under conditions of event-induced variance. Journal of Financial Economics, 30(2), 253-272. https://doi.org/10.1016/0304-405X(91)90032-F

Bomfim, A. N. (2003). Pre-announcement effects, news effects, and volatility: Monetary policy and the stock market. Journal of Banking and Finance. https://doi.org/10.1016/S0378-4266(01)00211-4

Borges, M. R. (2010). Efficient market hypothesis in European stock markets. The European Journal of Finance, 16(7), 711-726. https://doi.org/10.1080/1351847X.2010.495477

Bowman, R., \& Bucharan, J. (1995). The efficient market hypothesis: A discussion of institutional, agency and behavioural issues. Australian Journal of Management, 20(2). https://doi.org/10.1177/031289629502000203

Cajueiro, D. O., Gogas, P., \& Tabak, B. M. (2009). Does financial market liberalization increase the degree of market efficiency? The case of the Athens stock exchange. International Review of Financial Analysis, 18(1-2), 50-57. https://doi.org/10.1016/j.irfa.2008.11.004

Chance, D. M. (1985). A semi-strong form test of the efficiency of the treasury bond futures market. Journal of Futures Markets, 5(3), 385-405. https://doi.org/10.1002/fut.3990050309

Chordia, T., Roll, R., \& Subrahmanyam, A. (2008). Liquidity and market efficiency. Journal of Financial Economics, 87(2), 249-268. https://doi.org/10.1016/j.jfineco.2007.03.005

Coleman, L. (2012). Testing equity market efficiency around terrorist attacks. Applied Economics, 44(31), 4087-4099. https://doi.org/10.1080/00036846.2011.587778

Deepak, R., \& Shollapur, M. R. (2015). Impact of Economic Reforms on Stock Market Behaviour: A Short-Term Perspective, 9(December), 3-16. 
Derdas, S. I. (2012).Testing Semi-Strong Form Efficiency and the PEAD Anomaly in ATHEX: An Event Study based on Annual Earnings Announcements.

Dhar, S., \& Chhaochharia, S. (2008). Market Reaction Around the Stock Splits and Bonus Issues: Some Indian Evidence. SSRN Electronic Journal. https://doi.org/10.2139/ssrn.1087200

Dietrich, J. R., Kachelmeier, S. J., Kleinmuntz, D. N., \& Linsmeier, T. J. (2001). Market Efficiency, Bounded Rationality, and Supplemental Business Reporting Disclosures. Journal of Accounting Research, 39(2), $243-268$. https://doi.org/10.1111/1475-679X.00011

Elliott, J., Morse, D., \& Richardson, G. (1984). The Association between Insider Trading and Information Announcements. Rand Journal of Economics, 15(4), 521-536. https://doi.org/10.2307/2555523

Fama, E. F. (1970). Efficient Capital Markets-A Review of Theory and Empirical Work. The Journal of Finance, 25(2), 383-417. https://doi.org/10.2307/2329297

Federal Reserve Bank of St. Louis. (2009). The Financial Crisis. A Timeline of Events and Policy Actions. FRBS.

Gausiene, E., \& Jureviciene, D. (2010). Finansines gyventojų elgsenos ypatumai. Verslas: Teorija Ir Praktika, 11(3), 222237.

Gilson, R. J., \& Kraakman, R. (2014). Market Efficiency after the Crisis: It's still a Matter of Information Costs. Virginia Law Review. Virginia Law Review. https://doi.org/10.2307/24362691

Goss, B. A. (1983). The semi-strong form efficiency of the London Metal Exchange. Applied Economics, $15(5), 681$. https://doi.org/10.1080/00036848300000044

Gupta, A. (2006). Impact of earnings announcements on stock prices: some empirical evidences from India. The ICFAI Journal of Applied Finance, 12(3), 5-13.

Harris, L. (1993). The Winners and Losers of the Zero-Sum Game : The Origins of Trading Profits, Price Efficiency and Market Liquidity. Origins, (December 1991).

Hodrea, R. (2015). An Intraday Analysis of the Market Efficiency-liquidity Relationship: The Case of BVB Stock Exchange. Procedia Economics and Finance, 32, 1432-1441. https://doi.org/10.1016/S2212-5671(15)01519-1

Hoffmann, A. O. I., Post, T., \& Pennings, J. M. E. (2013). Individual investor perceptions and behavior during the financial crisis. Journal of Banking and Finance, 37(1), 60-74. https://doi.org/10.1016/j.jbankfin.2012.08.007

Hussin, B. M., Ahmed, A. D., \& Ying, T. C. (2010). Semi-Strong Form Efficiency: Market Reaction to Dividend and Earnings Announcements in Malaysian Stock Exchange. IUP Journal of Applied Finance, 16(5), 36-60.

Iqbal, T., \& Mallikarjunappa, T. (2007). Stock price reactions to earnings announcement. ACRM Journal of Business and Management Research, 2(1), 10-15.

Ito, M., \& Sugiyama, S. (2009). Measuring the degree of time varying market inefficiency. Economics Letters, 103(1), 6264. https://doi.org/10.1016/j.econlet.2009.01.028

Jazepcikaite, V. (2008). Baltic Stock Exchanges'Mergers: The Effects on the Market Efficiency Dynamics. Central European University, Budapest.

Kancerevycius, G. (2009). Finansai ir investicijos. Vilnius: Smaltija.

Kane, A., Lee, Y. K., \& Marcus, A. (1984). Earnings and Dividend Announcements: Is There a Corroboration Effect? The Journal of Finance, 39(4), 1091-1099. https://doi.org/10.1111/j.1540-6261.1984.tb03894.x

Kiete, K., \& Uloza, G. (2005). The Information Efficiency of the Stock Markets in Lithuania and Latvia. Stockholm School of Economics in Riga.

Klimasauskiene, D., \& Moscinskiene, V. (1998). Lietuvos kapitalo rinkos efektyvumo problema. Pinigu Studijos, 2, 25 -34.

Kolari, J. W., \& Pynnonen, S. (2010). Event study testing with cross-sectional correlation of abnormal returns. Review of Financial Studies, 23(11), 3996-4025. https://doi.org/10.1093/rfs/hhq072

Konceviciene, I. (2006). Vertybiniu popieriu birzu jungimosi sprendimų metodologiniai aspektai. (Lithuanian). Management of Organizations: Systematic Research, (40), 59-79.

Kumar, B. (2015). Event-Study of Dividend Announcements by Selected Public Sector Banks of India. SSRN Electronic Journal. https://doi.org/10.2139/ssrn.2813790

Laidroo, L. (2008). Public announcement induced market reactions on Baltic stock exchanges. Baltic Journal of Management, 3(2), 174-192. https://doi.org/10.1108/17465260810875505

Leipus, R., and Norvaisa, R. (2003). Finansų rinkų teorijų pagrindai. Pinigu Studijos, 4, 5-28.

Liargovas, P., \& Repousis, S. (2010). The Impact of Terrorism on Greek Banks ā€ ${ }^{\mathrm{TM}}$ Stocks : An Event Study. International Research Journal of Finance and Economics Issue, 51.

Mackey, A. M., \& Bacon, F. W. (2017). Signaling with Stock Isues and Repurchases: a Test of Semi-Strong Form Market Efficiency. Journal of Business and Behavioral Sciences, 29(1).

MacKinlay, A. (1997). Event studies in economics and finance. Journal of Economic Literature, 35(1), 13-39. 
Vilija Alekneviciene, Lauryna Kviedaraitiene, Egle Alekneviciute. Semi-Strong Form Efficiency in the Baltic Stock Markets...

https://doi.org/doi-not-found

Mahmood, F., Xinping, X., Shahid, H., \& Usman, M. (2010). Global Financial Crisis: Chinese Stock Market Efficiency. Asian Journal of Management Research, 90-101.

Maynes, E., \& Rumsey, J. (1993). Conducting event studies with thinly traded stocks. Journal of Banking \& Finance, 17(1), 145-157. https://doi.org/10.1016/0378-4266(93)90085-R

Minjina, D. I., \& Resceanu, O. (2008). Testing the Semi-Strong Form of the Efficient Market Hypothesis on Public Offers for Acquisition/Takeover in the Pharmaceutical and the Aluminium Sectors of the Romanian Capital Market. In Financial Innovation and Competition in European Union (p. 127). Bucharest.

Olweny, T. (2012). Dividend announcement and firm value: A test of semi strong form of efficiency at the nairobi stock exchange. Asian Social Science, 8(1), 161-175. https://doi.org/10.5539/ass.v8n1p161

Papaioannou, M. G., Park, J., Pihlman, J., \& Hoorn, H. Van Der. (2013). Procyclical Behavior of Institutional Investors During the Recent Financial Crisis: Causes, Impacts, and Challenges. IMF Working Papers, 13(193), 1. https://doi.org/10.5089/9781484336083.001

Patell, J. M. (1976). Corporate Forecasts of Earnings Per Share and Stock Price Behavior: Empirical Test. Journal of Accounting Research, 14(2), 246. https://doi.org/10.2307/2490543

Robinson, C. J., \& Bangwayo-skeete, P. (2016). Semi-Strong Form Market Efficiency in Thinly Traded Markets: Evidence from Stock Price Reaction to Major National and International Events, 1-25.

Roszkowski, M. J., \& Davey, G. (2010). Risk Perception and Risk Tolerance Changes Attributable to the 2008 Economic Crisis : A Subtle but Critical Difference. Journal of Financial Service Professionals, 64(4), 42-53.

Schaffer, M. P., Myers, R. J., \& Koontz, S. R. (2004). Rational expectations and market efficiency in the U.S. live cattle futures market: The role of proprietary information. Journal of Futures Markets, 24(5), 429-451. https://doi.org/10.1002/fut.10124

Sharma, R. (2011). Stock Price Behaviour around Dividend Announcements: An Event Study Methodology. Vilakshan: The XIMB Journal of Management, 8(2), 23-32.

Siourounis, G. (2002). Modelling volatility and testing for efficiency in emerging capital markets: The case of the Athens stock exchange. Applied Financial Economics, 12, 47-55. https://doi.org/10.1080/09603100110088003

Sturm, P. (2013). Operational and reputational risk in the European banking industry: The market reaction to operational risk events. Journal of Economic Behavior \& Organization, 85, 191-206. https://doi.org/10.1016/j.jebo.2012.04.005

Vosvorda, M., Filacek, J., \& Kapicka, M. (1998). The Efficient Market Hypothesis on the Prague Stock Exchange. Workshop to ACE Phare Project Paper.

Westfall, T. (2010). Stock split announcements: A test of market efficiency. Proceedings of the Academy of Accounting and Financial Studies, 15(1), 59-66.

Will, M. (2006). The Role of Performances in an Accounting Scandal: An Insider's Perspective on How Things Went Wrong. In Proceedings of 5th Global Conference on Business \& Economics, Cambridge University, UK.

Yao, J., Ma, C., \& He, W. P. (2014). Investor herding behaviour of Chinese stock market. International Review of Economics and Finance, 29, 12-29. https://doi.org/10.1016/j.iref.2013.03.002

Young, M., \& Bacon, F. (2012). The federal open market committee and the federal funds rate: A test of market efficiency. Academy of Banking Studies Journal, 11(2), 81-92.

Ziliotto, A., \& Serati, M. (2015). The semi-strong efficiency debate: In search of a new testing framework. Research in International Business and Finance, 34, 412-438. https://doi.org/10.1016/j.ribaf.2015.03.002

The article has been reviewed.

Received in September, 2017; accepted in December, 2018. 